OPEN ACCESS

Edited by:

Jiyang Cai,

University of Oklahoma Health Sciences Center, United States

Reviewed by:

Yousif Subhi,

Rigshospitalet, Denmark

Li Huang,

Fujian Medical University Union

Hospital, China

*Correspondence:

Moein Zangiabadian

zangiabadian1998@gmail.com

Mohammad Javad Nasiri

mj.nasiri@hotmail.com

Specialty section: This article was submitted to

Inflammatory Eye Diseases,

a section of the journal

Frontiers in Ophthalmology

Received: 16 August 2021 Accepted: 01 November 2021 Published: 01 December 2021

Citation:

Hatami H, Ghaffari Jolfayi A, Ebrahimi A, Golmohammadi S, Zangiabadian M and Nasiri MJ (2021) Contact Lens Associated

Bacterial Keratitis: Common Organisms, Antibiotic Therapy, and Global Resistance Trends: A Systematic Review.

Front. Ophthalmol. 1:759271. doi: 10.3389/fopht.2021.759271

\section{Contact Lens Associated Bacterial Keratitis: Common Organisms, Antibiotic Therapy, and Global Resistance Trends: A Systematic Review}

\author{
Hossein Hatami ${ }^{1}$, Amir Ghaffari Jolfayi ${ }^{2}$, Ali Ebrahimi ${ }^{2}$, Saeid Golmohammadi ${ }^{2}$, \\ Moein Zangiabadian ${ }^{2 *}$ and Mohammad Javad Nasiri ${ }^{3 *}$
}

\begin{abstract}
${ }^{1}$ Department of Public Health, School of Public Health and Environmental and Occupational Hazard Control Research Center, Shahid Beheshti University of Medical Sciences, Tehran, Iran, ${ }^{2}$ Student Research Committee, School of Medicine, Shahid Beheshti University of Medical Sciences, Tehran, Iran, ${ }^{3}$ Department of Microbiology, School of Medicine, Shahid Beheshti University of Medical Sciences, Tehran, Iran
\end{abstract}

Introduction: Contact lens wearing has been increased globally during recent decades, which is one of the main risk factors for developing microbial keratitis. Microbial keratitis is a severe and dangerous condition that causes cornea inflammation. It can lead to corneal scarring and perforation or even endophthalmitis and visual loss if it remains untreated. Among bacterial, fungal, protozoal, and viral agents which can cause microbial keratitis, bacteria are the most common cause. Therefore, in this study, we aim to find common causative bacteria, sensitivity, and resistance to antibiotics and the outcome of antibiotic therapy in contact lens-related bacterial keratitis.

Methods: A systematic search was carried out in PubMed/Medline, EMBASE, and Web of Science for published studies and medRxiv for preprints up to February 30, 2021, and May 14, 2021, respectively. A combination of the following keywords was used: "Infection", "Corneal infection", "Keratitis", "Microbial keratitis", and "Contact lens", Also, we used the "Contact lenses" MeSH term. Lists of references for each selected article and relevant review articles were hand-searched to identify further studies.

Results: Twenty-six articles were included. From 1991 to 2018, 2,916 episodes of contact lens-related microbial keratitis) CLMK(with 1,642 episodes of proven bacterial keratitis have been reviewed in these studies. Studies were conducted in 17 countries with different geographical regions, and four studies were conducted in Iran, which is the highest number of studies among these countries. According to 20 studies, the mean age of patients was 30.77 years. Females with $61.87 \%$ were more than males in 19 studies. A percentage of $92.3 \%$ of patients used soft contact lenses, and $7.7 \%$ of patients used hard contact lenses (including RGP), according to 16 studies. Pseudomonas aeruginosa, Staphylococcus spp., and Serratia marcescens were the three most common bacteria 
isolated from samples of patients with contact lens-related bacterial keratitis. Overall, isolated bacteria were most sensitive to fluoroquinolones and aminoglycosides, especially ciprofloxacin and gentamicin respectively, and most resistant against penicillin and cephalosporins especially cefazolin and chloramphenicol. Almost all patients responded well to antibiotic therapy, with some exceptions that needed further surgical interventions.

Conclusion: Antibiotics are efficient for treating almost all patients with contact lensrelated bacterial keratitis if they are appropriately chosen based on common germs in every geographical region and the sensitivity and resistance of these germs against them. In this regard, Pseudomonas aeruginosa is the most common causative germ of contact lens-associated bacterial keratitis all over the world and is almost fully sensitive to ciprofloxacin. Because of some different results about the sensitivity and resistance of germs against some antibiotics like gentamicin, vancomycin, and chloramphenicol in the Middle East region, especially Iran, more in vitro and clinical studies are suggested.

Keywords: contact lens, bacterial keratitis, antibiotic therapy, sensitivity, resistance

\section{INTRODUCTION}

During the recent decades, contact lens wearing has been increased globally from approximately 32 million in 2002 to 40.9 million adult ( $>18$ years old) wearers in 2014 only in the USA, and this number was 140 million worldwide $(1,2)$. The contact lens global market is estimated at 19.45 billion US dollars in 2024 (3). There are many types of contact lenses available for therapeutic and non-therapeutic purposes; soft and hard or rigid gas permeable (RGB) are two main types (4). Although modern contact lenses are safer than old ones, adverse events like corneal edema due to hypoxia, corneal abrasion, neovascularization, conjunctivitis, midday fogging, inflammation, and infection may occur (5). Contact lens wearing is a prevalent risk factor for microbial keratitis (MK), with an incident rate of approximately 2-20 cases per 10,000 wearers each year $(6,7)$. Various factors can increase the risk of contact lens-related microbial keratitis like professional occupation compared with being a student, discarding lenses yearly versus fewer periods, showering daily with wearing lenses versus never showering in lenses, and sleeping in lenses $(8,9)$. Procrastination of therapy results in corneal scarring and perforation, then maybe endophthalmitis and visual loss (10). MK could occur via bacterial, fungal, protozoal, and viral agents (11).

Bacterial keratitis is the most common cause of $\mathrm{MK}$, which accounts for about $90 \%$ of cases (12); manifestation of bacterial keratitis includes eye discomfort and redness, eyelid swelling, decreased sight, and photophobia (10). Correct identification of the causative pathogen and its virulence factors and using appropriate antibiotics can reduce extended and drastic treatment and avoid further antibiotic resistance. It is also associated with better outcomes and decreased surgical interventions (13).

This systematic review aimed to find common causative germs, sensitivity and resistance to antibiotics, and antibiotic therapy outcomes in contact lens-related bacterial keratitis.

\section{METHODS}

This systematic review was conducted according to the "Preferred Reporting Items for Systematic Reviews and Metaanalyses" (PRISMA) statement (14).

\section{Search Strategy}

A systematic search was carried out in the literature from the following bibliographical databases: PubMed/Medline, EMBASE, and Web of Science for published studies and medRxiv for preprints up to February 30, 2021, and May 14, 2021, respectively. Keyword searches were done with combinations of the terms "infection", "corneal infection", "keratitis", "microbial keratitis", and "contact lens". Also, we used the "contact lenses" MeSH term. Lists of references of selected articles and relevant review articles were hand-searched to identify further studies. There was no restriction on publication date, but only studies written in English were selected.

\section{Study Selection}

All potentially relevant English articles were screened in two stages for eligibility. Two reviewers independently reviewed titles and abstracts in the first stage. Study types that were included in this stage were clinical retrospective or prospective reviews of patients, case series, and cross-sectional studies that were about infectious keratitis and fit the full-text evaluation criteria. Review articles and case reports were excluded. Discrepancies at this step were discussed with a third reviewer. In the second assessment stage with full-text evaluation, we included studies that discussed contact lens-related bacterial keratitis and examined the sensitivity, resistance, and outcome of antibiotic therapies on common bacterial germs. Therefore, studies that had discussed about other etiological microorganisms such as amoebic, fungal, or viral agents or had focused on infectious keratitis due to 
factors other than contact lens such as traumatic or post-surgical keratitis were excluded. Other exclusion criteria were studies that discussed about rare causative bacteria, molecular or animal studies, and studies that discussed the protective use of antibiotics as antimicrobial solutions. Disagreements and technical uncertainties were discussed and resolved between review authors.

\section{Data Extraction}

The following variables were extracted from all included studies: first author, study interval, type of study, countries where the study was conducted, study population, number of patients with proven bacterial keratitis, sex and mean age of patients, contact lens regime, diagnostic microbiological tests for bacterial keratitis, and three common isolated bacteria. The three most common sensitive antibiotics and the most resistant ones, and the outcome of antibiotic therapy, were extracted from some studies. Two authors independently extracted the data from the selected studies. The data were jointly reconciled, and disagreements were discussed and resolved between review authors.

\section{RESULTS}

The selection process of articles is shown in Figure 1. Twenty-six articles were included and classified into the following: 15 retrospective reviews of patients (15-29), seven prospective reviews of patients (30-36), three cross-sectional studies (3739), and one case series (40). Four studies have been conducted in Iran; three in India; two studies in the USA, Australia,
Netherlands, China; and one study each in Switzerland, Portugal, Pakistan, Thailand, Brazil, Turkey, France, Egypt, UK, Japan, and Belgium (Table 1). A total of 2,916 episodes of CLMK with 1,642 episodes of proven bacterial keratitis (isolated or polymicrobial) have been reviewed in studies from 1991 to 2018 (Tables 1 and 2). According to 20 studies, the mean age of patients was 30.77 years. Females with $61.87 \%$ were more than males in nineteen studies. A percentage of $92.3 \%$ of patients used soft contact lenses, and $7.7 \%$ of patients used hard contact lenses (including RGP), according to 16 studies (Table 2). Diagnostic microbiological tests are shown in Table 2.

\section{The Most Common Isolated Bacteria}

Twenty-four of 26 studies perused the most common isolated bacteria from cultured samples; two of them $(16,38)$ only had Pseudomonas spp. in their survey. Among these 24 studies, Pseudomonas spp. especially Pseudomonas aeruginosa was the most common isolated bacteria from cultured samples (625 episodes among three common germs in studies with raw data) and were the first common bacteria in 18 studies and the second common bacteria in five studies. Only the study by Inoue et al. (18) had not reported Pseudomonas among its three common isolated bacteria. Staphylococcus spp. especially coagulase-negative staphylococcus spp. (CoNS) Staphylococcus epidermidis was the second most common bacteria from cultured samples. In five studies, they were the first common bacteria (438 episodes of Staphylococcus spp. and 364 episodes of coagulase-negative staphylococcus spp. among three common germs in studies with raw data). Serratia spp. was the third common bacteria, and in the study by Cheng et al. (35), Serratia

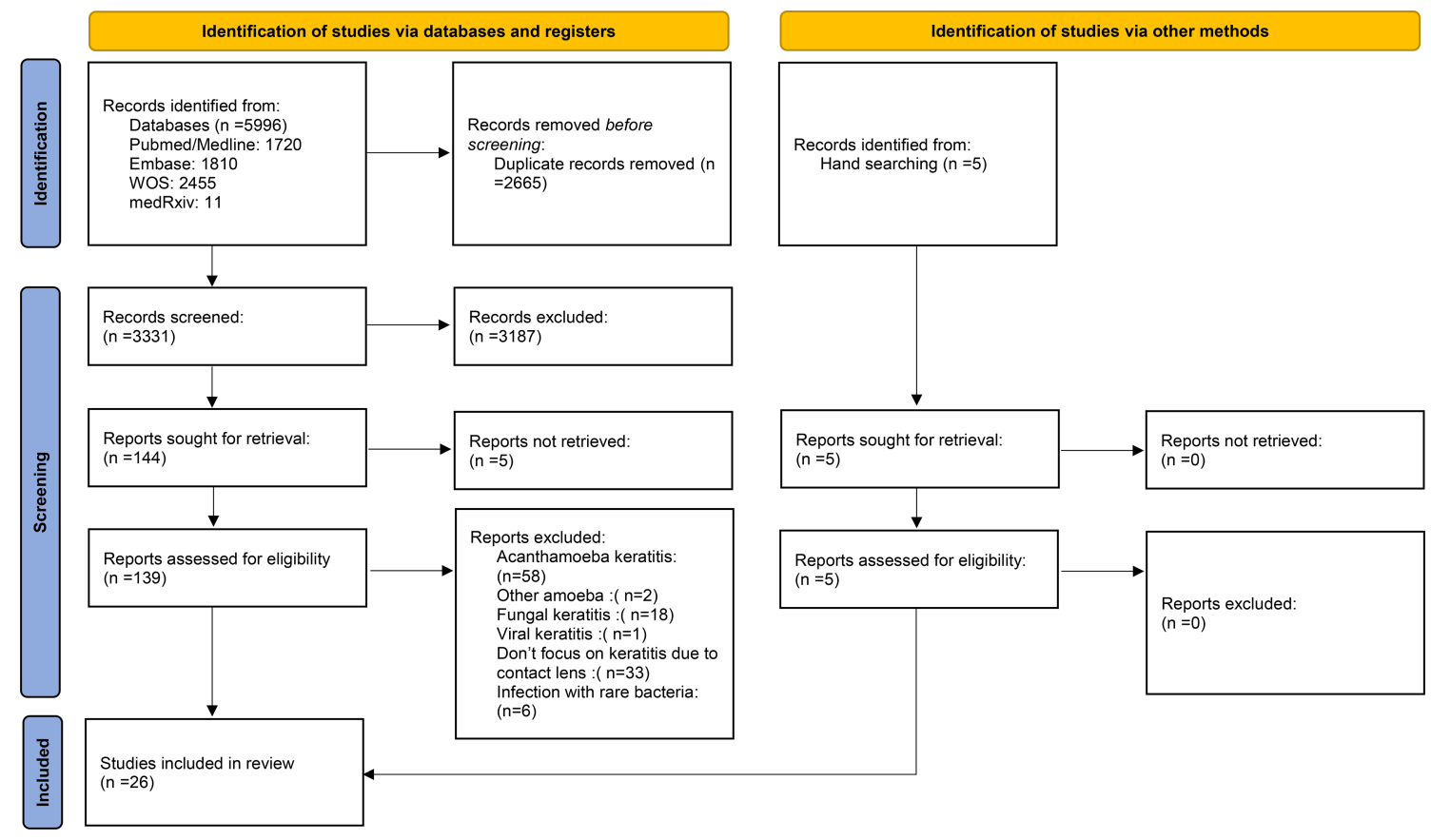

FIGURE 1 | PRISMA 2020 flow diagram for new systematic reviews which included searches of databases, registers, and other sources. 
TABLE 1 | Characteristics of all included studies.

Title of article
Microbial Analyses of Contact Lens-Associated Microbial Keratitis
Initial treatment of Pseudomonas aeruginosa contact lens-associated keratitis with topical
chloramphenicol, and effect on outcome
Study on Prevalence, Antibiotic Susceptibility, and tuf Gene Sequence-Based Genotyping of
Species-Level of Coagulase-Negative Staphylococcus Isolated From Keratitis Caused by
Using Soft Contact Lenses
Clinical Presentation and Antibiotic Susceptibility of Contact Lens Associated Microbial
Keratitis
Antibiotic Susceptibility Patterns of Pseudomonas Corneal Ulcers in Contact Lens Wearers
Sensitivity Pattern of Bacteria Isolated from Contact Lens Wearers in the Faculty of Pharmacy,
Karachi University Student Population
Clinical presentation and morbidity of contact lens-associated microbial keratitis: a
retrospective study
Contact Lens-Induced Infectious Keratitis in Japan

Contact lens-related microbial keratitis in Egypt: 5y epidemiological study

Clinical Presentation and Microbial Analyses of Contact Lens Keratitis; an Epidemiologic Study

Bacterial keratitis: Predisposing factors, clinical and microbiological review of 300 cases

Clinical and microbiological characteristics of corneal ulcers in a Thai referral center

Colored cosmetic contact lenses: An unsafe trend in the younger generation

Contact Lens Versus Non-Contact Lens-Related Corneal Ulcers at an Academic Center

Contact lens-associated microbial keratitis

Contact Lens-Associated Microbial Keratitis in a Tertiary Eye Care Center in Turkey

Bacterial keratitis: A prospective clinical and microbiological study

Clinical and Microbiological Profile of Bacterial Microbial Keratitis in a Portuguese Tertiary

Referral Center-Where Are We in 2015?

Contact lens-related corneal ulcers requiring hospitalization: A 7-year retrospective study in Belgium

Relationship Between Climate, Disease Severity, and Causative Organism for Contact LensAssociated Microbial Keratitis in Australia

Trends in Contact Lens-associated Microbial Keratitis in Southern India

Incidence of contact-lens-associated microbial keratitis and its related morbidity

\begin{tabular}{|c|c|c|c|}
\hline Author & Year & Country & $\begin{array}{c}\text { Type of } \\
\text { study }\end{array}$ \\
\hline
\end{tabular}

Konda et al. (15) January 2001 to India Retrospective

November 2011

review of

Bourkiza et al. 2007 to $2009 \quad$ UK Retrospective

(16)

(1)

review of

patients

Faghri et al. (30) January 2013 to Iran prospective

August 2013

Hedayati et al. June 2012 to June Iran

(37) 2013

Mohammadpour March 2009 to March Iran

et al. (38) 2010

Rahim et al. (31) February 2005 to

January 2006

Hoddenbach January 1,2005 , to

et al. (17) December 31, 2009

review of

patients

cross-

sectional

cross-

sectional

Pakistan prospective

review of

patients

Netherland Retrospective

review of

patients

Inoue et al. (18) From January 1999 to Japan Retrospective December 2003

Khater et al. (32) first of January $2009 \quad$ Egypt

to the end of

December 2013

Rasoulinejad

2011 to 2013

et al. (39)

Bourcier et al.

January 1998 to

September 1999

(19)

January 2006 and

Kampitak et al.

December 2010

(20)

November 2009

Singh et al. (40)

February 2010

Bennett et al. $\quad 1999$ to 2016

(21)

Moriyama et al.

(22)

January 2002 to

December 2007

Karaca et al. (23) 2012 to 2018

Schaefer et al.

March 1, 1997, to

Ferreira et al. November 30, 1998

(24)

September 2007 to

August 2015

Verhelst et al.

January 1997 to

(25)

December 2003

Stapleton et al.

(34)

October 1, 2003, and September 30, 2004

Sharma et al. (26)

February 1991 and September 2000

Cheng et al. (35) April 1 and June 30, 1996 patients

Prospective

review of

patients

Iran cross-

sectional

France Retrospective

review of

patients

review of

patients

India Case series

USA Retrospective

review of

patients

Brazil Retrospective

review of

patients

Turkey Retrospective

review of

patients

Switzerland Prospective

review of

patients

Portugal Retrospective

review of

patients

Belgium Retrospective

review of

patients

prospective

review of

patients

India Retrospective

review of

patients

Netherlands prospective

review of

patients
Thailand Retrospective 
TABLE 1 | Continued

\begin{tabular}{|c|c|c|c|c|}
\hline Title of article & Author & Year & Country & $\begin{array}{l}\text { Type of } \\
\text { study }\end{array}$ \\
\hline Microbial Keratitis Profile at a University Hospital in Hong Kong & Lai et al. (27) & $\begin{array}{l}\text { January } 2010 \text { to June } \\
2012\end{array}$ & China & $\begin{array}{l}\text { Retrospective } \\
\text { review of } \\
\text { patients }\end{array}$ \\
\hline $\begin{array}{l}\text { Incidence and risk factors for microbial keratitis in Hong Kong: comparison with Europe and } \\
\text { North America }\end{array}$ & Lam et al. (36) & $\begin{array}{l}\text { April } 1997 \text { and August } \\
1998\end{array}$ & China & $\begin{array}{l}\text { prospective } \\
\text { review of } \\
\text { patients }\end{array}$ \\
\hline Trends in contact lens microbial keratitis 1999 to 2015: a retrospective clinical review & Green et al. (29) & $\begin{array}{l}\text { January } 1999 \text { to } \\
\text { December } 2015\end{array}$ & Australia & $\begin{array}{l}\text { Retrospective } \\
\text { review of } \\
\text { patients }\end{array}$ \\
\hline $\begin{array}{l}\text { Visual Outcome, Microbiological Profile and Antibiotic Sensitivity of Infectious Keratitis in a } \\
\text { Tertiary Referral Center }\end{array}$ & $\begin{array}{l}\text { Stanfield et al. } \\
(28)\end{array}$ & $\begin{array}{l}\text { January } 1,2014 \text { to } \\
\text { December } 31,2018\end{array}$ & USA & $\begin{array}{l}\text { Retrospective } \\
\text { review of } \\
\text { patients }\end{array}$ \\
\hline
\end{tabular}

UK, United Kingdom; USA, United States of America.

marcescens and Pseudomonas aeruginosa were the first common bacteria from cultured samples (44 episodes among three common germs in studies with raw data). Ferreira et al. (23) and Verhelst et al. (24) noticed that Pseudomonas aeruginosa was significantly associated with a worse clinical manifestation than other causative organisms. The risk of microbial keratitis in extended-wear and also daily-wear soft contact lenses was greater than that in daily-wear RGP lenses according to Cheng et al. (34). Bourcier et al. (18) and Rasoulinejad et al. (38) mentioned that gram-negative bacteria especially Pseudomonas aeruginosa were more associated with soft contact lenses, whereas according to Inoue et al. (17), gram-positive bacteria like staphylococcus species were the most common bacteria in soft and hard contact lenses.

The three most common bacteria that were isolated from samples in each study are shown in Table 3.

\section{Sensitivity and Resistance to Antibiotics}

Fifteen studies reported the sensitivity and resistance of isolated bacteria to antibiotics. Eight studies reported the sensitivity and resistance of each bacteria separately. In the remaining seven studies, only the overall sensitivity and resistance of discussed bacteria to antibiotics were reported. In studies by Mohammadpour et al. (38) and Bourkiza et al. (16) which only discussed the treatment of Pseudomonas spp., isolated bacteria were $100 \%$ sensitive to fluoroquinolones, especially ciprofloxacin. Also, isolated bacteria in the study by Mohammadpour et al. (38) were $100 \%$ sensitive to ceftazidime. Green et al. (29) reported that none of the cultured isolates of $P$. aeruginosa was resistant to fluoroquinolones. Lai et al. (27) and Moriyama et al. (22) noticed that cultured Pseudomonas aeruginosa samples were $100 \%$ sensitive to ciprofloxacin and gentamicin in the former study and ciprofloxacin, ofloxacin, gatifloxacin, amikacin, and tobramycin in the latter. Hoddenbach et al. (17) showed that $P$. aeruginosa is sensitive to ofloxacin and gentamicin by $98.7 \%$ and $97.3 \%$, respectively, and Bennett et al. (21) noticed that P. aeruginosa is $100 \%$ sensitive to oxacillin. On the other hand, Rahim et al. (31) represented that $P$. aeruginosa had $82 \%$ sensitivity to ciprofloxacin and was most sensitive to imipenem with $84.4 \%$ sensitivity. In the study by Singh et al. (40), P. aeruginosa had only $57.1 \%$ and $14.2 \%$ sensitivity to other fluoroquinolones like moxifloxacin and levofloxacin, respectively. According to studies by Hedayati et al. (37) and Rasoulinejad et al. (39), P. aeruginosa is $100 \%$ resistant to gentamicin. Hoddenbach et al. (17) noticed that resistance to cefazolin in P. aeruginosa is $99.3 \%$. Isolated P. aeruginosa in the study by Bourkiza et al. (16) showed $100 \%$ resistance to chloramphenicol, but Mohammadpour et al. (38) showed $100 \%$ resistance for cefazolin and vancomycin and 97\% for chloramphenicol.

S. epidermidis and S. aureus, according to Rahim et al. (31), had the most sensitivity to imipenem with $100 \%$ sensitivity. In this study, ciprofloxacin is in second place in which S. aureus showed $100 \%$ sensitivity and S. epidermidis $92.9 \%$ sensitivity to it. Moriyama et al. (22) represented that coagulase-negative staphylococcus spp. had $100 \%$ sensitivity to ciprofloxacin, ofloxacin, amikacin, tobramycin, gentamicin, cephalothin, and oxacillin. S. aureus and CoNS in the study by Bennett et al. (21) showed $87 \%$ and $83 \%$ sensitivity to oxacillin, respectively. Conversely, Singh et al. (40) reported that the S. aureus sensitivity to moxifloxacin, levofloxacin, and amikacin was $33.3 \%$, and S. epidermidis was 50\% sensitive to moxifloxacin. In the study by Hedayati et al. (37), all three S. aureus samples were resistant to ciprofloxacin but were sensitive to gentamicin.

Hoddenbach et al. (17) showed that Serratia spp. were $100 \%$ sensitive to gentamicin and $90 \%$ sensitive to ofloxacin but were $90 \%$ resistant to cefazolin. Also, Karaca et al. (23) reported that both Serratia marcescens and P. aeruginosa were $100 \%$ sensitive to vancomycin and ceftazidime.

Among studies that reported the overall sensitivity and resistance of all discussed bacteria (gram-negative and grampositive bacteria like P. aeruginosa, Serratia spp., S. epidermidis, S. aureus, etc.) to antibiotics, bacteria were most sensitive to ciprofloxacin in studies by Hedayati et al. (37) and Rasoulinejad et al. (39) with $86 \%$ and $71.4 \%$ sensitivity in each study respectively. Also, ciprofloxacin was the second and third antibiotics in the studies by Sharma et al. (26)and Faghri et al. (30) in which bacteria had the most sensitivity to it, with $88 \%$ and $86.8 \%$, respectively. In these two studies, gentamicin was the first antibiotic in that order, in which bacteria had $100 \%$ 
TABLE 2 | Epidemiologic and demographic features of studies.

\begin{tabular}{|c|c|c|c|c|c|c|}
\hline Author & $\begin{array}{c}\text { Study } \\
\text { population }\end{array}$ & $\begin{array}{c}\text { No. proven } \\
\text { bacterial keratitis }\end{array}$ & $\begin{array}{l}\text { Age in } \\
\text { years } \\
\text { (mean) }\end{array}$ & Sex & Contact lens types & Microbiological tests \\
\hline Konda et al. (15) & $\begin{array}{l}125 \text { eyes of } 123 \\
\text { patients }\end{array}$ & $\begin{array}{c}83 \\
(71 \%)\end{array}$ & $\begin{array}{l}24.14 \text { in } \\
\text { male } \\
26.7 \text { in } \\
\text { female } \\
\text { total: } \\
25.38\end{array}$ & $\begin{array}{l}63 \text { male }(51.2 \%) \text { and } \\
60 \text { female }(48.8 \%)\end{array}$ & - & $\begin{array}{l}\text { Corneal culture } \\
\text { Contact lens culture } \\
\text { Contact lens case culture }\end{array}$ \\
\hline Bourkiza et al. (16) & 139 patients & $\begin{array}{c}139 \\
(100 \%)\end{array}$ & 28 & $\begin{array}{l}57 \text { male }(41 \%) \text { and } \\
82 \text { female }(59 \%)\end{array}$ & $\begin{array}{l}\text { Soft: } 121(87 \%) \\
\text { RGP: } 4 \text { (2.8\%) } \\
\text { Cosmetic: } 2(1.4 \%) \\
\text { Therapeutic: } 6(4.3 \%) \\
\text { Not recorded: } 6 \\
(4.3 \%)\end{array}$ & $\begin{array}{l}\text { Corneal cultures with Gram-negative } \\
\text { bacterial isolates }\end{array}$ \\
\hline Faghri et al. (30) & 77 patients & $\begin{array}{c}60 \\
(80 \%)\end{array}$ & 26 & $\begin{array}{l}23 \text { male }(29.8 \%) \text { and } \\
54 \text { female }(70.2 \%)\end{array}$ & Soft: 77 (100\%) & $\begin{array}{l}\text { Corneal culture } \\
\text { tuf gene sequencing }\end{array}$ \\
\hline Hedayati et al. (37) & $\begin{array}{l}33 \text { eyes of } 26 \\
\text { patients }\end{array}$ & $\begin{array}{c}25 \\
(75.7 \%)\end{array}$ & 23.88 & $\begin{array}{l}2 \text { male }(7.7 \%) \text { and } \\
24 \text { female }(92.3 \%)\end{array}$ & Soft: 26 (100\%) & Corneal scraping culture \\
\hline Mohammadpour et al. (38) & 52 patients & $\begin{array}{c}52 \\
(100 \%)\end{array}$ & 21.5 & $\begin{array}{l}9 \text { male }(17.3 \%) \text { and } \\
43 \text { female }(82.7 \%)\end{array}$ & Soft: 52 (100\%) & $\begin{array}{l}\text { Perform smears for gram staining and } \\
\text { then culture the specimens }\end{array}$ \\
\hline Rahim et al. (31) & 100 patients & $\begin{array}{c}100 \\
(100 \%)\end{array}$ & - & - & - & $\begin{array}{l}\text { Culture of bacterial isolates from } \\
\text { conjunctiva }\end{array}$ \\
\hline Hoddenbach et al. (17) & 109 patients & - & 33.3 & $\begin{array}{l}\text { Male: } 42.2 \%(46) \\
\text { Female: } 57.8 \%(63)\end{array}$ & $\begin{array}{l}\text { Soft: } 97(88.9 \%) \\
\text { RGP: } 12(11.1 \%)\end{array}$ & $\begin{array}{l}\text { Corneal culture } \\
\text { Contact lens culture } \\
\text { contact lens box culture }\end{array}$ \\
\hline Inoue et al. (18) & $\begin{array}{l}67 \text { eyes of } 66 \\
\text { patients }\end{array}$ & - & 37 & $\begin{array}{l}\text { Male-to-female ratio } \\
\text { was 1:0.91 } \\
35 \text { male }(52.35 \%) \\
\text { and } 31 \text { female } \\
(47.65 \%)\end{array}$ & $\begin{array}{l}\text { Soft: } 48(71.6 \%) \\
\text { Hard (including RGP): } \\
19(22.4 \%)\end{array}$ & $\begin{array}{l}\text { Culture of corneal scrapings or eye } \\
\text { discharge or contact lens or contact } \\
\text { lens preservative solution }\end{array}$ \\
\hline Khater et al. (32) & 151 patients & $\begin{array}{c}\text { Only bacteria } 43 \\
(28.5 \%) \\
\text { Mixed bacteria and } \\
\text { fungi } \\
53(35.1 \%)\end{array}$ & 31 & $\begin{array}{l}18 \text { male }(11.9 \%) \text { and } \\
133 \text { female }(88.1 \%)\end{array}$ & - & $\begin{array}{l}\text { Culture of storage cases solutions or } \\
\text { the contact lens itself besides corneal } \\
\text { swabs or biopsy }\end{array}$ \\
\hline Rasoulinejad et al. (39) & $\begin{array}{l}17 \text { eyes of } 14 \\
\text { patients }\end{array}$ & $14(82.3 \%)$ & 21.58 & 14 female (100\%) & Soft: 14 (100\%) & Corneal culture \\
\hline Bourcier et al. (19) & 151 eyes & $95(62.9 \%)$ & 32 & - & $\begin{array}{l}\text { Soft: } 135(89.4 \%( \\
\text { RGP: } 13(8.6 \%) \\
\text { Hard PMMA: } 3(2 \%)\end{array}$ & $\begin{array}{l}\text { Corneal culture } \\
\text { Contact lens culture } \\
\text { Storage cases culture }\end{array}$ \\
\hline Kampitak et al. (20) & 35 patients & $10(29 \%)$ & 25.6 & $\begin{array}{l}5(14.3 \%) \text { male and } \\
30 \text { female }(85.7 \%)\end{array}$ & - & Corneal culture \\
\hline Singh et al. (40) & 13 patients & 12 (92.3\%) & 19 & $\begin{array}{l}8 \text { male }(61.5 \%) \text { and } \\
5 \text { female }(38.5 \%)\end{array}$ & - & Corneal culture \\
\hline Bennett et al. (21) & 319 patients & $116(36.3 \%)$ & 32.7 & $\begin{array}{l}121 \text { male (38\%) and } \\
198 \text { female }(62 \%)\end{array}$ & - & Corneal culture \\
\hline Moriyama et al. (22) & 239 patients & $166(69.4 \%)$ & 29.75 & $\begin{array}{l}\text { Male-to-female ratio } \\
1: 1.26 \\
106 \text { male }(44.25 \%) \\
\text { and } 133 \text { female } \\
(55.75 \%)\end{array}$ & $\begin{array}{l}\text { Soft: } 96(88.07 \%) \\
\text { RGP: } 11(10.09 \%) \\
\text { Piggy-back lenses: } 2 \\
(1.83 \%)\end{array}$ & Corneal culture \\
\hline Karaca et al. (23) & 62 patients & $40(64.5 \%)$ & 24.5 & $\begin{array}{l}22 \text { male }(35.4 \%) \text { and } \\
40 \text { female }(64.6 \%)\end{array}$ & $\begin{array}{l}\text { Soft: } 61(98.4 \%) \\
\text { RGP: } 1(1.6 \%)\end{array}$ & $\begin{array}{l}\text { Corneal culture } \\
\text { Contact lens culture } \\
\text { Storage cases culture }\end{array}$ \\
\hline Schaefer et al. (33) & 31 patients & $28(90.3 \%)$ & - & - & - & Corneal culture \\
\hline Ferreira et al. (24) & 65 patients & - & 36 & - & - & Corneal culture \\
\hline Verhelst et al. (25) & 107 patients & $72(67.2 \%)$ & 28.8 & $\begin{array}{l}42 \text { male }(39.2 \%) \\
65 \text { female }(60.8 \%)\end{array}$ & $\begin{array}{l}\text { Soft: } 99(92.5 \%) \\
\text { RGP: } 8(7.5 \%)\end{array}$ & $\begin{array}{l}\text { Corneal culture } \\
\text { Contact lens culture } \\
\text { Storage cases culture }\end{array}$ \\
\hline Stapleton et al. (34) & 236 patients & 59 (25\%) & - & - & - & Corneal culture \\
\hline Sharma et al. (26) & 28 patients & 25 (89.2\%) & 22.3 & $\begin{array}{l}12 \text { male }(42.8 \%) \\
16 \text { female }(57.2 \%)\end{array}$ & $\begin{array}{l}\text { Soft: } 15(53.5 \%) \\
\text { RGP: } 6(21.4 \%) \\
\text { Therapeutic bandage }\end{array}$ & Corneal culture \\
\hline
\end{tabular}


TABLE 2 | Continued

\begin{tabular}{|c|c|c|c|c|c|c|}
\hline Author & $\begin{array}{c}\text { Study } \\
\text { population }\end{array}$ & $\begin{array}{c}\text { No. proven } \\
\text { bacterial keratitis }\end{array}$ & $\begin{array}{l}\text { Age in } \\
\text { years } \\
\text { (mean) }\end{array}$ & Sex & Contact lens types & Microbiological tests \\
\hline & & & & & $\begin{array}{l}\text { contact lenses: } 4 \\
(14.2 \%) \\
\text { SilSoft lenses: } 3 \\
(10.7 \%)\end{array}$ & \\
\hline Cheng et al. (35) & 92 patients & $29(31.5 \%)$ & 32.6 & $\begin{array}{l}47 \text { male }(51 \%) \\
45 \text { female }(49 \%)\end{array}$ & $\begin{array}{l}\text { Soft: } 75 \text { (82\%) } \\
\text { RGP: } 17(18 \%)\end{array}$ & Corneal culture \\
\hline Lai et al. (27) & 23 patients & $14(60.8 \%)$ & 27.7 & - & Soft: 23 (100\%) & Corneal culture \\
\hline Lam et al. (36) & 59 patients & $\begin{array}{l}22 \text { isolates } \\
\text { (including } \\
\text { polymicrobial } \\
\text { cultures) }\end{array}$ & - & $\begin{array}{l}20 \text { male }(34 \%) \\
39 \text { female }(66 \%)\end{array}$ & $\begin{array}{l}\text { Soft: } 58(98 \%) \\
\text { RGP: } 1(2 \%)\end{array}$ & Corneal culture \\
\hline Green et al. (29) & $\begin{array}{l}372 \text { CLMK } \\
\text { episodes of } 324 \\
\text { patients }\end{array}$ & $\begin{array}{c}357 \text { CLBK episodes } \\
(96 \%)\end{array}$ & 36.47 & $\begin{array}{l}43.2 \% \text { male }(140) \\
\text { and } 56.8 \% \text { female } \\
(184)\end{array}$ & $\begin{array}{l}\text { Soft: } 215(66.4 \%) \\
\text { RGP: } 6(1.9 \%)\end{array}$ & Corneal scrape culture \\
\hline Stanfield et al. (28) & 214 eyes & $71(33.1 \%)$ & - & - & - & Culturing for a corneal infection \\
\hline
\end{tabular}

CLMK, contact lens related microbial keratitis; CLBK, contact lens related bacterial keratitis.

sensitivity in the study by Faghri et al. (30) and 92\% sensitivity in that of Sharma et al. (26). Other fluoroquinolones were discussed in the study by Konda et al. (15), and gatifloxacin, ofloxacin, and gentamicin were the first three antibiotics that bacteria were most sensitive to, with $89 \%, 88 \%$, and $86 \%$ sensitivity to each of them, respectively. Green et al. (29) reported that P. aeruginosa, S. epidermidis, and S. aureus had $100 \%$ sensitivity to vancomycin. Bacteria had $100 \%$ resistance to penicillin in two studies $(37,39)$ and $71.1 \%$ resistance in another study (30). Konda et al. (15) reported that Pseudomonas spp., Serratia spp., and CoNS were most resistant to chloramphenicol, while in the study by Faghri et al. (30), these bacteria had $94.7 \%$ sensitivity to chloramphenicol. Bacteria in the study by Green et al. (29) were most resistant against cephalosporins. For example, all bacteria excluding Enterobacter had 100\% resistance against cefixime in the study by Rasoulinejad et al. (39) and had 56\% resistance against cefazolin in Sharma et al. (26). The three most effective antibiotics and the most ineffective ones are shown in Table 4.

\section{The Outcome of Antibiotic Therapy}

The outcome of experimental or antibiogram-guided antimicrobial therapy was discussed in 11 studies. Therapeutic penetrating keratoplasty, therapeutic graft, amniotic membrane transplantation, anterior lamellar keratoplasty, anterior lamellar corneal transplants, RGB lens, and phototherapeutic keratectomy were additional therapies in patients that did not respond to antibiotic therapy and had complications like corneal perforation. Singh et al. (40) represented that treatment outcome was good among all cases with prescribed topical antimicrobials, and none of them have required surgical interventions; also, in the study by Konda et al. (15), approximately all patients were treated with choosing antibiotics via antibiogram. Among 61 pseudomonas spp., four of them showed in vitro resistance to multiple antibiotics containing aminoglycosides, fluoroquinolones, and third cephalosporins. Three cases showed the relevant clinical results to ciprofloxacin eye drops, and one case needed penetrating keratoplasty due to insufficiency of medical therapy. Mohammadpour et al. (38) observed $81 \%$ prosperous clinical response with antibiotic therapy, and Sharma et al. (26) noticed that among 28 patients, ulcers of 24 (85.7\%) patients were healed with laboratory-based medical therapy, while other patients needed penetrating keratoplasty. According to the study by Bourkiza et al. (16), experimental use of chloramphenicol against Pseudomonas spp. leads to greater ulcer size and worse visual acuity at presentation to the hospital, more median interval to final follow-up, and more complications like a vascularized scar. However, VA at the final review was not statistically different between chloramphenicol and non-chloramphenicol groups. Hoddenbach et al. (17) reported that three perforating keratoplasties were managed in an emergency setting because of corneal perforation due to Pseudomonas aeruginosa. Karaca et al. (23) studied that the mean best-corrected visual acuity (BCVA) increased with antibiotic therapy, and according to culture results, $P$. aeruginosa infections were associated with significantly worse BCVA. In the study by Green et al. (29), only one 68-year-old female had a poor outcome due to cultured MRSA from scraping cornea resistant to multiantibiotics like cephalosporins and fluoroquinolones. Finally, she was treated with topical vancomycin while her visual acuity was hand movements. Twenty-one patients (6.5\%) with CLMK required surgical interventions or showed complications in this study. The outcome of antibiotic therapy is shown in Table 5.

\section{DISCUSSION}

Among the reviewed articles, the most common isolated bacteria were Pseudomonas aeruginosa which was considered separately in the two articles due to its high prevalence and importance of treatment. Although it was not reported as a common germ in some studies, no other bacteria were mentioned besides $P$. aeruginosa in all reviewed studies. The next common organism was Staphylococcus spp. especially coagulase-negative spp. such 
TABLE 3 | Three most common bacteria in studies.

\begin{tabular}{|c|c|c|c|}
\hline Author & The first most common bacteria & The second most common bacteria & The third most common bacteria \\
\hline Konda et al. (15) & $\begin{array}{l}\text { Pseudomonas spp. } \\
61(73.5 \%)\end{array}$ & $\begin{array}{l}\text { Staphylococcus epidermidis } \\
4(4.8 \%) \\
\text { Serratia spp. } \\
4(4.8 \%)\end{array}$ & $\begin{array}{l}\text { Other coagulase-negative staphylococci } \\
2(2.4 \%)\end{array}$ \\
\hline Bourkiza et al. (16) & $\begin{array}{l}139 \text { Pseudomonas spp. among } 149 \text { cases with } \\
\text { culture-proven Gram-negative organisms }\end{array}$ & $\begin{array}{l}10 \text { Serratia spp. among } 149 \text { cases with culture- } \\
\text { proven Gram-negative organisms }\end{array}$ & - \\
\hline Faghri et al. (30) & $\begin{array}{l}\text { Coagulase-negative staphylococcus } \\
38(49.3 \%) \\
\text { (S. epidermidis: } 31)\end{array}$ & $\begin{array}{l}\text { Pseudomonas aeruginosa } \\
5(7 \%) \\
\text { Enterobacter aerogenes } \\
5(7 \%)\end{array}$ & $\begin{array}{l}\text { Micrococcus luteus } \\
3(3.9 \%) \\
\text { Bacillus spp. } \\
3(3.9 \%) \\
\text { Serratia spp. } \\
3(3.9 \%) \\
\text { Klebsiella spp. } \\
3 \text { (3.9\%) }\end{array}$ \\
\hline Hedayati et al. (37) & $\begin{array}{l}\text { Pseudomonas aeruginosa } \\
20(80 \%)\end{array}$ & $\begin{array}{l}\text { Staphylococcus aureus } \\
3(12 \%)\end{array}$ & $\begin{array}{l}\text { Enterobacter } \\
2(8 \%)\end{array}$ \\
\hline $\begin{array}{l}\text { Mohammadpour } \\
\text { et al. (38) }\end{array}$ & $\begin{array}{l}\text { Pseudomonas aeruginosa } \\
52(100 \%)\end{array}$ & - & - \\
\hline Rahim et al. (31) & $\begin{array}{l}\text { S. epidermidis } \\
41(41 \%)\end{array}$ & $\begin{array}{l}\text { Pseudomonas aeruginosa } \\
39(39 \%)\end{array}$ & $\begin{array}{l}\text { S. aureus } \\
11(11 \%)\end{array}$ \\
\hline $\begin{array}{l}\text { Hoddenbach et al. } \\
\text { (17) }\end{array}$ & $\begin{array}{l}\text { Pseudomonas aeruginosa } \\
68.8 \%\end{array}$ & Serratia spp. & Stenotrophomonas maltophilia \\
\hline Inoue et al. (18) & $\begin{array}{l}\text { Staphylococcus epidermidis } \\
13(36.1 \%)\end{array}$ & $\begin{array}{l}\text { Staphylococcus aureus } \\
5(14.3 \%)\end{array}$ & $\begin{array}{l}\text { Corynebacterium spp. } \\
4(11.4 \%)\end{array}$ \\
\hline Khater et al. (32) & $\begin{array}{l}\text { Gram positive bacteria } \\
\text { (S. aureus, S. epidermidis, pneumococci) } \\
27(63 \%)\end{array}$ & $\begin{array}{l}\text { Gram-negative bacteria } \\
\text { (Pseudomonas aeruginosa) } \\
16(37 \%)\end{array}$ & - \\
\hline Rasoulinejad et al. & Pseudomonas aeruginosa & Staphylococcus aureus & Enterobacter \\
\hline (39) & $11(78.6 \%)$ & $2(14.3 \%)$ & $1(7.1 \%)$ \\
\hline Bourcier et al. (19) & Coagulase negative staphylococcus 47 (49.4\%) & Pseudomonas aeruginosa 18 (18.9\%) & Propionibacterium acnes 14 (14.7\%) \\
\hline Kampitak et al. (20) & Pseudomonas aeruginosa 9 (90\%) & Acinetobacter baumannii 1 (10\%) & - \\
\hline Singh et al. (40) & Pseudomonas aeruginosa 7 (54\%) & Staphylococcus aureus 3 (25\%) & Staphylococcus epidermidis 2 (17\%) \\
\hline Bennett et al. & Pseudomonas spp. 62 (53.4\%) & Coagulase negative staphylococcus 17 (14.6\%) & Staphylococcus aureus 15 (12.9\%) \\
\hline Moriyama et al. (22) & Coagulase negative staphylococcus 74 (44.5\%) & Pseudomonas spp. 32 (19.2\%) & Corynebacterium spp. 20 (12\%) \\
\hline Karaca et al. (23) & Pseudomonas aeruginosa 17 (42.5\%) & Serratia marcescens 8 (20\%) & Stenotrophomonas maltophilia 5 (12.5\%) \\
\hline Schaefer et al. (33) & $\begin{array}{l}\text { Gram negative bacteria } 12 \text { (43\%) } \\
\text { mostly Pseudomonas species }\end{array}$ & - & - \\
\hline Ferreira et al. (24) & Pseudomonas aeruginosa $36.3 \%$ & Serratia spp. $18 \%$ & $\begin{array}{l}\text { S. epidermidis and other coagulase- } \\
\text { negative Staphylococcus } 13.6 \%\end{array}$ \\
\hline Verhelst et al. (25) & Pseudomonas aeruginosa 54 (75\%) & Serratia marcescens 16 (22.2\%) & Klebsiella oxytoca 10 (13.8\%) \\
\hline Stapleton et al. (34) & Pseudomonas spp. 35 (59.3\%) & Serratia spp. 6 (10.1\%) & $\begin{array}{l}\text { Staphylococcus aureus } 4(6.7 \%) \\
\text { Coagulase-negative staphylococcus } 4 \\
(6.7 \%)\end{array}$ \\
\hline Sharma et al. (26) & Pseudomonas spp. 13 (52\%) & Staphylococcus spp. 6 (24\%) & Streptococcus spp. 4 (16\%) \\
\hline Cheng et al. (35) & $\begin{array}{l}\text { Pseudomonas aeruginosa } 7 \text { (24.1\%) } \\
\text { Serratia marcescens } 7 \text { (24.1\%) }\end{array}$ & Staphylococcus spp. 6 (20.6\%) & Enterobacter spp. 5 (17.2\%) \\
\hline Lai et al. (27) & Pseudomonas aeruginosa 13 (92.8\%) & - & - \\
\hline Lam et al. (36) & Pseudomonas aeruginosa 12 (54.5\%) & $\begin{array}{l}\text { Gram-positive bacteria } 5(22.7 \%) \\
\text { Gram-negative bacteria other than P. } \\
\text { aeruginosa } 5(22.7 \%)\end{array}$ & - \\
\hline Green et al. (29) & Pseudomonas aeruginosa 181 (50.70\%) & Coagulase-negative Staphylococci 111 (31\%) & $\begin{array}{l}\text { Staphylococcus aureus (non-MRSA) } 10 \\
(2.8 \%)\end{array}$ \\
\hline Stanfield et al. (28) & Pseudomonas aeruginosa 29 (40.8\%) & Staphylococcus epidermidis 11 (15.5\%) & Staphylococcus aureus 9 (12.6\%) \\
\hline
\end{tabular}

as Staphylococcus epidermidis, and the third organism was Serratia marcescens. In some articles' rankings, these agents fluctuated, but because of different geographical areas where studies were conducted, somehow variation in the frequency of microorganisms is acceptable and not so far unexpected.

In the treatment approaches, Pseudomonas is most considered in the studies, and there is a consensus on notable sensitivity to fluoroquinolones, especially ciprofloxacin as a drug of choice in this issue. Ofloxacin and gatifloxacin are two effective antibiotics against Pseudomonas, but moxifloxacin and levofloxacin which are other members of fluoroquinolones were not effective in this regard; these antibiotics are known as respiratory fluoroquinolones, and their inefficacy as a topical drug is presumable (41).

Mohammadpour et al. (38), Bourkiza et al. (16), Lai et al. (27), and Moriyama et al. (22) mentioned that P. aeruginosa was $100 \%$ 
TABLE 4 | The three most effective and the most ineffective antibiotics.

\begin{tabular}{|c|c|c|c|c|}
\hline Author & The first most effective antibiotic & $\begin{array}{c}\text { The second most effective } \\
\text { antibiotic }\end{array}$ & $\begin{array}{l}\text { The third most effective } \\
\text { antibiotic }\end{array}$ & The most ineffective antibiotic \\
\hline Konda et al. (15) & $\begin{array}{l}\text { Gatifloxacin } \\
89 \%\end{array}$ & $\begin{array}{l}\text { Ofloxacin } \\
88 \%\end{array}$ & $\begin{array}{l}\text { Gentamicin } \\
87 \%\end{array}$ & Chloramphenicol \\
\hline Bourkiza et al. (16) & $\begin{array}{l}\text { Fluoroquinolone (ciprofloxacin) } \\
100 \%\end{array}$ & - & - & $\begin{array}{l}\text { Chloramphenicol } \\
100 \%\end{array}$ \\
\hline Faghri et al. (30) & $\begin{array}{l}\text { Gentamicin } \\
100 \%\end{array}$ & $\begin{array}{l}\text { Chloramphenicol } \\
94.7 \%\end{array}$ & $\begin{array}{l}\text { Ciprofloxacin } \\
86.8 \%\end{array}$ & $\begin{array}{l}\text { Penicillin } \\
71.1 \%\end{array}$ \\
\hline Hedayati et al. (37) & $\begin{array}{l}\text { Ciprofloxacin } \\
86 \%\end{array}$ & $\begin{array}{l}\text { Imipenem, meropenem, and } \\
\text { ceftazidime } \\
76 \%\end{array}$ & - & $\begin{array}{l}\text { Penicillin } \\
100 \%\end{array}$ \\
\hline $\begin{array}{l}\text { Mohammadpour } \\
\text { et al. (38) }\end{array}$ & $\begin{array}{l}\text { Ceftazidime and ciprofloxacin } \\
100 \%\end{array}$ & $\begin{array}{l}\text { Amikacin } \\
97 \%\end{array}$ & $\begin{array}{l}\text { Imipenem } \\
96 \%\end{array}$ & $\begin{array}{l}\text { Cefazolin and vancomycin } \\
100 \%\end{array}$ \\
\hline Rahim et al. (31) & $\begin{array}{l}\text { Imipenem } \\
100 \% \text { for S. epidermidis } \\
\text { and S. aureus } \\
84.4 \% \text { for } \text { P. aeruginosa }\end{array}$ & $\begin{array}{l}\text { Ciprofloxacin } \\
100 \% \text { for S. aureus } \\
92.9 \% \text { for } \text { S. epidermidis } \\
82 \% \text { for } P \text {. aeruginosa }\end{array}$ & - & $\begin{array}{l}\text { Amoxicillin, cephradine, neomycin, and } \\
\text { chloramphenicol }\end{array}$ \\
\hline $\begin{array}{l}\text { Hoddenbach et al. } \\
\text { (17) }\end{array}$ & $\begin{array}{l}\text { Ofloxacin } \\
100 \% \text { for S. maltophilia } \\
98.7 \% \text { for P. aeruginosa } \\
90 \% \text { for Serratia spp }\end{array}$ & $\begin{array}{l}\text { Gentamicin } \\
100 \% \text { for Serratia spp. } \\
97.3 \% \text { for P. aeruginosa } \\
57.1 \% \text { for S. maltophilia }\end{array}$ & - & $\begin{array}{l}\text { Cephazolin } \\
100 \% \text { for S. maltophilia } \\
99.3 \% \text { for P. aeruginosa } \\
90 \% \text { for Serratia spp. }\end{array}$ \\
\hline $\begin{array}{l}\text { Rasoulinejad et al. } \\
\text { (39) }\end{array}$ & $\begin{array}{l}\text { Ciprofloxacin, } \\
71.4 \%\end{array}$ & $\begin{array}{l}\text { ceftazidime, imipenem, and } \\
\text { meropenem }\end{array}$ & & $\begin{array}{l}\text { Penicillin } \\
100 \%\end{array}$ \\
\hline Singh et al. (40) & $\begin{array}{l}\text { Moxifloxacin } \\
57.1 \% \text { for } \mathrm{P} . \text { aeruginosa } \\
\text { 33.3\% for } \text { S. aureus } \\
50 \% \text { for } \text { S. epidermidis }\end{array}$ & $\begin{array}{l}\text { Amikacin } \\
28.5 \% \text { for } P \text {. aeruginosa } \\
\text { 33.3\% for } S \text {. aureus }\end{array}$ & $\begin{array}{l}\text { Levofloxacin } \\
\text { 14.2\% for } P \text {. aeruginosa } \\
\text { 33.3\% for } S . \text { aureus }\end{array}$ & - \\
\hline Bennett et al. (21) & $\begin{array}{l}\text { Oxacillin } \\
100 \% \text { for P. aeruginosa } \\
87 \% \text { for S. aureus } \\
83 \% \text { for CoNS }\end{array}$ & - & - & - \\
\hline Moriyama et al. (22) & $\begin{array}{l}\text { Ciprofloxacin and ofloxacin and amikacin } \\
\text { and tobramycin } \\
100 \% \text { for CoNS and P. aeruginosa }\end{array}$ & $\begin{array}{l}\text { Gatifloxacin } \\
100 \% \text { for P. aeruginosa } \\
97 \% \text { for CoNS } \\
\text { Gentamicin } \\
100 \% \text { for CoNS } \\
97 \% \text { for P. aeruginosa } \\
\text { Cephalothin and oxacillin } \\
100 \% \text { for CoNS }\end{array}$ & - & - \\
\hline Karaca et al. (23) & $\begin{array}{l}\text { Vancomycin and ceftazidime } \\
100 \%\end{array}$ & - & - & - \\
\hline Sharma et al. (26) & $\begin{array}{l}\text { Gentamicin } \\
92 \%\end{array}$ & $\begin{array}{l}\text { Ciprofloxacin } \\
88 \%\end{array}$ & $\begin{array}{l}\text { Cefazolin } \\
44 \%\end{array}$ & - \\
\hline Lai et al. (27) & $\begin{array}{l}\text { Gentamicin and ciprofloxacin } \\
100 \%\end{array}$ & - & - & - \\
\hline Green et al. (29) & $\begin{array}{l}\text { Vancomycin } \\
100 \%\end{array}$ & Fluoroquinolones & Chloramphenicol & Cephalosporins \\
\hline
\end{tabular}

CoNS, coagulase negative staphylococcus.

sensitive to ciprofloxacin, but some studies like Rahim et al. (31) have mentioned not complete but $82 \%$ sensitivity to this antibiotic. Due to the critical role of ciprofloxacin as a leading antibiotic in the eradication of $\mathrm{P}$. aeruginosa, this slight change in sensitivity should be noticed. According to the date of studies, the study by Rahim et al. (31) is conducted before those of Mohammadpour et al. (38), Bourkiza et al. (16), and Lai et al. (27), so antibiotic resistance development is not probable. We should also consider that the studies by Mohammadpour et al. (38) and Rahim et al. (31) were conducted in two proximal geographical areas respectively in Iran and Pakistan, so we do not expect so many differences between these two studies. This difference may be related to the source of the isolated bacteria in the study by Rahim et al. (31) which was from the conjunctiva, but this hypothesis needs more investigation.

Using ciprofloxacin as an antibiotic for Staphylococcus spp. was confirmed by the study of Rahim et al. (31) in which S. aureus had complete sensitivity to ciprofloxacin, but conversely, in a study held by Hedayati et al. (37), all three S. aureus samples were resistant to ciprofloxacin. It can be supposed that this is due to the small sample size and therefore a sampling bias, but a $100 \%$ resistance even in a small sample size is remarkable. The study by Rahim et al. (31) was held in Pakistan, from February 2005 to January 2006, and the study by Hedayati et al. (37) was performed in Iran from June 2012 to June 2013. According to the same geographical area of both studies and also that the second 
TABLE 5 | Outcome of antibiotic therapy.

\begin{tabular}{|c|c|}
\hline Author & Outcome \\
\hline Konda et al. (15) & $\begin{array}{l}\text { Approximately all patients were treated with choosing antibiotics via antibiogram. Among } 61 \text { pseudomonas spp., four of them showed in vitro } \\
\text { resistance to multiple antibiotics containing aminoglycosides, fluoroquinolones, and third cephalosporins. Three cases showed suitable clinical result } \\
\text { to ciprofloxacin eye drops. One case needs penetration of keratoplasty due to insufficiency of medical therapy. }\end{array}$ \\
\hline $\begin{array}{l}\text { Bourkiza et al. } \\
\text { (16) }\end{array}$ & $\begin{array}{l}\text { At presentation to the hospital, the chloramphenicol group had a larger size of ulcer and worse VA than the non-chloramphenicol group, while final } \\
\text { VA was not statistically different in the final examination. The average period follow-up of patients for the chloramphenicol group was } 37 \text { days } \\
\text { versus } 21 \text { days for the non-chloramphenicol group. Six complications including } 3 \text { vascularized scar and } 3 \text { therapeutic graft happen in the } \\
\text { chloramphenicol group versus } 2 \text { therapeutic graft in the non-chloramphenicol group. }\end{array}$ \\
\hline $\begin{array}{l}\text { Hedayati et al. } \\
\text { (37) }\end{array}$ & $\begin{array}{l}\text { Among all cases, } 57.7 \% \text { were treated outpatients; } 34.6 \% \text { and } 7.7 \% \text { of them were admitted and need to surgical interventions, respectively. The } \\
\text { median treatment interval was } 31 \pm 6 \text { days in the outpatient case and } 84 \pm 12 \text { days in the inpatient case. Treatment outcomes were excellent in } \\
24.2 \% \text {, good in } 45.5 \% \text {, and poor in } 30.3 \% \text { based on results. }\end{array}$ \\
\hline $\begin{array}{l}\text { Mohammadpour } \\
\text { et al. (38) }\end{array}$ & $\begin{array}{l}39 \text { cases }(75 \%) \text { required hospitalization, while } 13 \text { cases (25\%) were managed in outpatient and none of the patients needed hospitalization during } \\
\text { the follow-up. A prosperous clinical response of } 81 \% \text { was seen with antibiotic therapy. Ten cases (10\%) with mean age of } 21 \text { years and } 4 \times 4 \text { mm } \\
\text { corneal ulcer on average required amniotic membrane transplantation and } 58 \% \text { of them had hypopyon. }\end{array}$ \\
\hline $\begin{array}{l}\text { Hoddenbach } \\
\text { et al. (17) }\end{array}$ & $\begin{array}{l}\text { Corneal transplantation was needed for } 22 \text { eyes (20.2\%), including } 17 \text { perforating keratoplasties, } 3 \text { deep anterior lamellar keratoplasties, and } 2 \\
\text { anterior lamellar corneal transplants. Due to corneal perforation, three patients with perforating keratoplasty were managed in emergency settings } \\
\text { and } 19 \text { keratoplasties were conducted for culture-positive samples of P. aeruginosa due to major loss of visual acuity because of scarring. None of } \\
\text { the cases required evisceration or enucleation. Forty-seven patients (43.1\%) needed rigid gas permeable (RGP) lenses for achieving proper vision, } \\
\text { whereas } 33 \text { patients ( } 30.3 \%) \text { did not need further interventions like RGP or surgery. }\end{array}$ \\
\hline $\begin{array}{l}\text { Rasoulinejad et } \\
\text { al. (39) }\end{array}$ & Outcome of treatment was excellent in $23.5 \%$, good in $47.1 \%$, and poor in $29.4 \%$ of patients that required penetrating keratoplasty intervention \\
\hline Singh et al. (40) & Treatment outcome was good among all cases with prescribed topical antimicrobials, and none of them required surgical interventions. \\
\hline Karaca et al. (23) & $\begin{array}{l}\text { There was a significant negative correlation between best-corrected visual acuity (BCVA) and P. aeruginosa keratitis. } \\
\text { At the end of follow-up, the mean BCVA was increased from } 0.7 \text { log of minimal angle of resolution (logMAR) (0-3) to } 0.1 \text { logMAR (0-0.4). } \\
\text { Average time for hospitalization was } 16.7 \text { days, for complete healing was } 16.7 \text { mouth and } 6.3 \text { mouth for follow-up. }\end{array}$ \\
\hline $\begin{array}{l}\text { Sharma et al. } \\
\text { (26) }\end{array}$ & $\begin{array}{l}\text { Among } 28 \text { patients, ulcers of } 24(85.7 \%) \text { patients were healed the ulcers with laboratory-based medical therapy, while other patients needed } \\
\text { penetrating keratoplasty. }\end{array}$ \\
\hline $\begin{array}{l}\text { Lai } \\
\text { et al. (27) }\end{array}$ & $\begin{array}{l}\text { On presentation, the mean logMAR visual acuity of all patients was } 0.99 \text { and was increased to } 0.34 \text { and } 0.26 \text { at } 1 \text { and } 3 \text { months after treatment, } \\
\text { respectively. Only } 37 \text { and } 19 \text { cases were recorded at } 1 \text { and } 3 \text { months, respectively, due to neglecting follow-up or being released from clinic. The } \\
\text { mean logMAR visual acuity was improved }-0.77 \text { at } 3 \text { months in between } 19 \text { patients. }\end{array}$ \\
\hline Green et al. (29) & $\begin{array}{l}\text { Among all CLMK cases only one 68-year-old female had a poor outcome related to cultured MRSA from scraping cornea that was resistant to } \\
\text { multi-antibiotics like cephalosporins and fluoroquinolones. Finally, she was treated with topical vancomycin while her visual acuity was hand } \\
\text { movements. } \\
21 \text { patients (6.5\%) with CLMK required surgical interventions or showed complications, which included penetrating keratoplasty in } 18 \text { (6.1\%) } \\
\text { patients, phototherapeutic keratectomy in } 2 \text { cases, and } 2 \text { patients had corneal perforation. }\end{array}$ \\
\hline
\end{tabular}

VA, visual acuity; CLMK, contact lens related microbial keratitis.

study was about 6 years later, we can assume developing a new emerging antibiotic resistance among the $S$. aureus species in this area, but due to the small sample size, our evidence has not enough strength to prove it. Another assumption can be related to the microbiological tests that in the study by Hedayati et al. (37), samples were retrieved from the corneal scraping culture, but Rahim et al. (31) studied the germs isolated from the conjunctiva. Also, this resistance may be related to the purpose of the contact lens (cosmetic or therapeutic); as Hedayati et al. (37) mentioned, cosmetic contact lens users had less education about contact lens hygiene compared to patients who wore therapeutic contact lenses, but Rahim et al. (31) did not mention the number of users in each category.

Gentamicin has been studied by Lai et al. (27), Moriyama et al. (22), and Hoddenbach et al. (17), and they proved that $P$. aeruginosa is completely sensitive to it, but conversely in the studies conducted by Hedayati et al. (37) and Rasoulinejad et al. (39), $P$. aeruginosa was $100 \%$ resistant to this antibiotic. This paradoxical result firstly can be interpreted by the region in which the study is conducted. Hedayati et al. (37) and Rasoulinejad et al. (39) performed their studies in Iran, but studies by Lai et al. (27) and Moriyama et al. (22) and Hoddenbach et al. (17) were conducted respectively in China,
Brazil, and the Netherlands. Thus, it can be concluded that in the Middle East especially Iran, P. aeruginosa species have developed antibiotic resistance to gentamicin. According to the date of studies, although Moriyama et al. (22) and Hoddenbach et al. (17) studied this issue between 2003 to 2009, Lai et al. (27) performed the study in about the same time as Hedayati et al. (37) and Rasoulinejad et al. (39) did between 2010 to 2013; therefore, this resistance is probably regional, and at least when the studies were conducted, the resistance was not spread to other regions. Most of these studies used the corneal culture method for identifying the bacteria, so we cannot attribute it to the sampling method. We should notice that there was another study in this area, Iran, which is conducted by Mohammadpour et al. (38) between 2009 to 2010 who studied on 52 patients with Pseudomonas keratitis exclusively and declared that Pseudomonas is $93 \%$ sensitive to gentamicin. This controversy between these three studies which were all held in Iran is doubtful, and antibiotic resistance mutation occurrence in about a 2-year interval seems impossible. This issue needs more investigations, and this resistance in Iran and probably surrounding countries should be considered in the treatment of $P$. aeruginosa keratitis and gentamicin prescription for bacterial keratitis should be avoided. 
Konda et al. (15) declared that Pseudomonas spp., Serratia spp., and CoNS are most resistant against chloramphenicol, while Faghri et al. (30) demonstrated that these germs had $94.7 \%$ sensitivity to chloramphenicol. Konda et al. (15) performed the study on 125 patients from January 2001 to November 2011 in India, but Faghri et al. (30) held it on 77 patients in Iran, from January 2013 to August 2013. Both studies are prospective with a notable sample size and both used corneal cultures, but Konda et al. (15) also used contact lens and contact lens case cultures. One of the reasons for this meaningful difference in the sensitivity profile of chloramphenicol could be attributed to the dominant organism in the study by Konda et al. (15), which was Pseudomonas spp. (73.5\%), However, in the study by Faghri et al. (30), the dominant organism was coagulase-negative Staphylococcus (49.3\%), and Pseudomonas was only responsible for $7 \%$ of the cases. Thus, it can change the overall response to the treatment. We should notice that Konda et al. (15) did not report the percent of resistance to chloramphenicol, and Faghri et al. (30) calculated the overall sensitivity of microorganisms to chloramphenicol. However, the proximity of Iran and India and the short time interval between these two studies, as well as the remarkable sample size of these studies, make this meaningful difference more doubtful!

Karaca et al. (23) and Green et al. (29) reported that $P$. aeruginosa was $100 \%$ sensitive to vancomycin, but Mohammadpour et al. (38) mentioned complete resistance to vancomycin. Mohammadpour et al. (38) performed their study on 52 patients with exclusively Pseudomonas bacterial keratitis in Iran from March 2009 to March 2010 and used smears for gram staining and then cultured the specimens. Karaca et al. (23) studied 62 patients in Turkey from 2002 to 2018 and used corneal, contact lens, and storage case cultures. Green et al. (29) made an investigation in Australia, from January 1999 to December 2015, with 372 episodes of CLMK that were proved by corneal scraping cultures. These studies had non-different methods for isolation and identification of the organisms, and these differences cannot be attributed to the methodological issues. Also, as mentioned previously, the type of contact lens (therapeutic or cosmetic) could be an essential factor. In the study by Mohammadpour et al. (38), only $14 \%$ of the patients had therapeutic contact lenses. However, in the study by Karaca et al. (23), 85.5\% of the patients had therapeutic contact lenses, and we previously mentioned that low education level in the cosmetic contact lens users might be related to the consequent outcomes. It also can be attributed to the different subspecies with various vancomycin genetic resistances, but according to the proximity of Iran and Turkey, this meaningful difference needs to be investigated more in the future.

While most of the similar articles were narrative review studies, we considered all of the related articles over time as a systematic review in this article. One of the strengths of the present study is that it reveals the controversies among different studies and, according to the standard and rational events, suggests some assumptions or logical reasons. On the other hand, there is an agreement in most of the details between this article and other previous similar systematic review studies that were written by Willcox (42), Mattila et al. (43),
Eggink et al. (44), and Zimmerman et al. (45). There has been a consensus on this issue in which Pseudomonas is the most common bacterial organism in microbial keratitis, and the fluoroquinolone family, especially ciprofloxacin, is the first-line treatment. Another essential strength point of this study is its recency; the last review study in this issue was performed by Willcox (42) in 2012, and in the last 9 years, there were no similar studies. Most of the previous studies did not focus on bacterial keratitis exclusively and reviewed Acanthamoeba keratitis alone or along with bacterial keratitis. They also usually discussed other risk factors rather than focusing on contact lens-induced keratitis, and sometimes they approached the risk factors, epidemiologic factors, and other issues but did not focus on antibiotic treatment and antibiotic sensitivity profile. However, in this article, we discussed that bacterial keratitis only related to contact lens wear and its antibiotic treatment and antibiotic sensitivity profile.

There were also limitations in this study. Some of the articles which were selected for the review were written in a language other than English, e.g., Chinese, and we could not use them for review. On the other hand, the total number of articles that met the inclusion criteria was limited. In reviewing the treatment approaches, we did not consider combination therapy, while some studies like those of Willcox (42) and Zimmerman et al. (45) paid great attention to combination therapy instead of monotherapy. Corticosteroid therapy is also considered in the study of Zimmerman et al. (45) as an important part of treatment, unlike our study.

\section{Suggestions}

Around the world, Pseudomonas is sensitive and responds well to gentamicin, but in the Iran region, in different studies, converse results have been observed $(37,39)$.

S. aureus was sensitive to ciprofloxacin, but in the study conducted by Hedayati et al. (24), all three S. aureus samples were resistant to it.

As a broad-spectrum antibiotic, vancomycin is a potent antibiotic that most germs respond to and is prescribed empirically $(23,29)$. It has been proven in various studies that vancomycin is an effective anti-Pseudomonas agent. However, the existence of $100 \%$ resistance to this antibiotic in a study (38) with a considerable sample size can be indicative of a developing resistance among the bacteria in the Middle East, and because of the broad use of this antibiotic in hospital settings, developing resistance is an important and serious issue.

In addition, although resistance to chloramphenicol has been proven in most studies, in a study conducted in Iran (30), a significant sensitivity was reported.

Almost all of these converse results were detected in the Middle East region, especially Iran and Pakistan, so more investigation is needed to reveal the underlying reason for these events. We suggest future in vitro molecular studies to identify different subspecies, developing antibiotic resistance and genetic mutations in this regard.

Sampling from various places such as conjunctiva or corneal scrapings may significantly affect the final result of the sensitivity profile test in the reviewed articles. Consequently, different 
sources of isolated bacteria may lead to different antibiotic sensitivity profiles even in the same geographical areas. In this regard, it is suggested to evaluate the effect of sampling from different places in future studies.

For systemic Pseudomonas infections in nosocomial settings, piperacillin/tazobactam as an anti-Pseudomonas antibiotic is commonly used (46). Also, for the treatment of non-contact lens-related keratitis, topical piperacillin/tazobactam is used in resistant keratitis cases as an effective antibiotic and has promising outcomes (47). Therefore, for future studies, the response to treatment with this antibiotic in the severe resistant cases of contact lens-related bacterial keratitis can be evaluated.

\section{CONCLUSION}

Among the reviewed articles, Pseudomonas aeruginosa was the most common bacteria, and Staphylococcus spp. such as S. aureus and Coagulase-negative spp. were the second, and Serratia marcescens was the third one. Commonly isolated bacteria were most sensitive to fluoroquinolones and aminoglycosides, especially ciprofloxacin and gentamicin, respectively, and most resistant against penicillin, cephalosporins, and chloramphenicol. Almost all patients responded well to antibiotic therapy, and some untreated cases needed further surgical interventions. In most of the reviewed studies, bacteria were susceptible to gentamicin and vancomycin

\section{REFERENCES}

1. Moreddu R, Vigolo D, Yetisen AK. Contact Lens Technology: From Fundamentals to Applications. Adv Healthc Mater (2019) 8(15):e1900368. doi: 10.1002/adhm.201900368

2. Cheung N, Nagra P, Hammersmith K. Emerging Trends in Contact LensRelated Infections. Curr Opin Ophthalmol (2016) 27(4):327-32. doi: 10.1097/ ICU.0000000000000280

3. Statista. Value of the Global Contact Lens Market From 2017 to 2024. Available at: https://www.statista.com/statistics/485820/global-value-of-thecontact-lens-market/.

4. Ahuja M. Contact Lens Wear and Microbial Keratitis. J Indian Med Assoc (2002) 100(11):664-6. doi: 10.1089/jop.2008.0047

5. Fuller DG, Wang Y. Safety and Efficacy of Scleral Lenses for Keratoconus. Optom Vis Sci (2020) 97(9):741-8. doi: 10.1097/OPX.0000000000001578

6. Stapleton F, Carnt N. Contact Lens-Related Microbial Keratitis: How Have Epidemiology and Genetics Helped Us With Pathogenesis and Prophylaxis. Eye (Lond) (2012) 26(2):185-93. doi: 10.1038/eye.2011.288

7. Fleiszig SMJ, Kroken AR, Nieto V, Grosser MR, Wan SJ, Metruccio MME, et al. Contact Lens-Related Corneal Infection: Intrinsic Resistance and its Compromise. Prog Retin Eye Res (2020) 76:100804. doi: 10.1016/j.preteyeres.2019.100804

8. Stellwagen A, MacGregor C, Kung R, Konstantopoulos A, Hossain P. Personal Hygiene Risk Factors for Contact Lens-Related Microbial Keratitis. BMJ Open Ophthalmol (2020) 5(1):e000476. doi: 10.1136/ bmjophth-2020-000476

9. Konda N, Garg P, Sharma S, Willcox MDP. Risk Factors for Contact LensRelated Microbial Keratitis and Associated Vision Loss in a South Indian Population. Eye Contact Lens (2021) 47(2):118-26. doi: 10.1097/ ICL.0000000000000737

10. Alkatan HM, Al-Essa RS. Challenges in the Diagnosis of Microbial Keratitis: A Detailed Review With Update and General Guidelines. Saudi J Ophthalmol (2019) 33(3):268-76. doi: 10.1016/j.sjopt.2019.09.002 and fully resistant against chloramphenicol. However, in the Middle East region, especially Iran, there were some different results about these antibiotics, which need more in vitro and clinical studies about the sensitivity and resistance of germs against them.

\section{DATA AVAILABILITY STATEMENT}

The original contributions presented in the study are included in the article/supplementary material. Further inquiries can be directed to the corresponding authors.

\section{AUTHOR CONTRIBUTIONS}

HH, MZ, MN: designed the study. MZ, AG, AE, SG: performed the search, study selection, and data synthesis. $\mathrm{HH}, \mathrm{MZ}, \mathrm{AG}, \mathrm{AE}$, SG: wrote the first draft of the manuscript. MN, MZ, HH: revised the article. All authors contributed to the article and approved the submitted version.

\section{ACKNOWLEDGMENTS}

This study is related to the PMH project From the Department of Public Health, School of Public Health and Safety, Shahid Beheshti University of Medical Sciences, Tehran, Iran.

11. Bartimote C, Foster J, Watson S. The Spectrum of Microbial Keratitis: An Updated Review. Open Ophthalmol J (2019) 13(1):100-30. doi: 10.2174/ 1874364101913010100

12. Musa F, Tailor R, Gao A, Hutley E, Rauz S, Scott R. Contact Lens-Related Microbial Keratitis in Deployed British Military Personnel. Br J Ophthalmol (2010) 94(8):988-93. doi: 10.1136/bjo.2009.161430

13. Lee JW, Somerville T, Kaye SB, Romano V. Staphylococcus Aureus Keratitis: Incidence, Pathophysiology, Risk Factors and Novel Strategies for Treatment. J Clin Med (2021) 10(4):100-30. doi: 10.3390/jcm 10040758

14. Moher D, Liberati A, Tetzlaff J, Altman DG. Preferred Reporting Items for Systematic Reviews and Meta-Analyses: The PRISMA Statement. Int J Surg (2010) 8(5):336-41. doi: 10.1016/j.ijsu.2010.02.007

15. Konda N, Motukupally SR, Garg P, Sharma S, Ali MH, Willcox MD. Microbial Analyses of Contact Lens-Associated Microbial Keratitis. Optom Vision Sci (2014) 91(1):47-53. doi: 10.1097/OPX.0000000000000082

16. Bourkiza R, Kaye S, Bunce C, Shankar J, Neal T, Tuft S. Initial Treatment of Pseudomonas Aeruginosa Contact Lens-Associated Keratitis With Topical Chloramphenicol, and Effect on Outcome. Br J Ophthalmol (2013) 97(4):42932. doi: 10.1136/bjophthalmol-2012-302251

17. Hoddenbach JG, Boekhoorn SS, Wubbels R, Vreugdenhil W, Van Rooij J, Geerards AJM. Clinical Presentation and Morbidity of Contact Lens-Associated Microbial Keratitis: A Retrospective Study. Graefes Arch Clin Exp Ophthalmol (2014) 252(2):299-306. doi: 10.1007/s00417-013-2514-1

18. Inoue N, Toshida H, Mamada N, Kogure N, Murakami A. Contact LensInduced Infectious Keratitis in Japan. Eye Contact Lens (2007) 33(2):65-9. doi: 10.1097/01.icl.0000233869.21964.1b

19. Bourcier T, Thomas F, Borderie V, Chaumeil C, Laroche L. Bacterial Keratitis: Predisposing Factors, Clinical and Microbiological Review of 300 Cases. Br J Ophthalmol (2003) 87(7):834-8. doi: 10.1136/bjo.87.7.834

20. Kampitak K, Suntisetsin H, Sirikul T. Clinical and Microbiological Characteristics of Corneal Ulcers in a Thai Referral Center. Asian Biomed (2014) 8(2):275-82. doi: 10.5372/1905-7415.0802.290 
21. Bennett L, Hsu H, Tai S, Ernst B, Schmidt EJ, Parihar R, et al. Contact Lens Versus Non-Contact Lens-Related Corneal Ulcers at an Academic Center. Eye Contact Lens (2019) 45(5):301-5. doi: 10.1097/ICL.0000000000000568

22. Moriyama AS, Hofling-Lima AL. Contact Lens-Associated Microbial Keratitis. Arq Bras Oftalmol (2008) 71(6 Suppl):32-6. doi: 10.1590/S000427492008000700007

23. Karaca I, Barut Selver O, Palamar M, Egrilmez S, Aydemir S, Yagci A. Contact Lens-Associated Microbial Keratitis in a Tertiary Eye Care Center in Turkey. Eye Contact Lens (2020) 46(2):110-5. doi: 10.1097/ICL.0000000000000617

24. Ferreira CS, Figueira L, Moreira-Gonçalves N, Moreira R, Torrão L, FalcãoReis F. Clinical and Microbiological Profile of Bacterial Microbial Keratitis in a Portuguese Tertiary Referral Center-Where Are We in 2015? Eye Contact Lens (2018) 44(1):15-20. doi: 10.1097/ICL.0000000000000298

25. Verhelst D, Koppen C, Van Looveren J, Meheus A, Tassignon MJ, Belgian Keratitis Study G. Contact Lens-Related Corneal Ulcers Requiring Hospitalization: A 7-Year Retrospective Study in Belgium. Acta Ophthalmol Scand (2006) 84(4):522-6. doi: 10.1111/j.1600-0420.2006.00681.x

26. Sharma S, Gopalakrishnan S, Aasuri MK, Garg P, Rao GN. Trends in Contact Lens-Associated Microbial Keratitis in Southern India. Ophthalmology (2003) 110(1):138-43. doi: 10.1016/S0161-6420(02)01283-6

27. Lai TH, Jhanji V, Young AL. Microbial Keratitis Profile at a University Hospital in Hong Kong. Int Sch Res Notices (2014) 2014:1-4. doi: 10.1155/ 2014/689742

28. Stanfield K, Huang B, Adah O, Ladner M, McClung D, Matherne B, et al. Visual Outcome, Microbiological Profile and Antibiotic Sensitivity of Infectious Keratitis in a Tertiary Referral Center. Invest Ophthalmol Visual Sci (2020) 61(7). doi: 10.21203/rs.3.rs-38733/v1

29. Green M, Sara S, Hughes I, Apel A, Stapleton F. Trends in Contact Lens Microbial Keratitis 1999 to 2015: A Retrospective Clinical Review. Clin Exp Ophthalmol (2019) 47(6):726-32. doi: 10.1111/ceo.13484

30. Faghri J, Zandi A, Peiman A, Fazeli H, Esfahani BN, Safaei HG, et al. Study on Prevalence, Antibiotic Susceptibility, and Tuf Gene Sequence-Based Genotyping of Species-Level of Coagulase-Negative Staphylococcus Isolated From Keratitis Caused by Using Soft Contact Lenses. Eye Contact Lens (2016) 42(2):115-9. doi: 10.1097/ICL.0000000000000066

31. Rahim N, Bano H, Naqvi B. Sensitivity Pattern of Bacteria Isolated From Contact Lens Wearers in the Faculty of Pharmacy, Karachi University Student Population. Iran J Pharm Res (2008) 7(2):131-4. doi: 10.22037/IJPR.2010.755

32. Khater MM, El-Shorbagy MS. Contact Lens-Related Microbial Keratitis in Egypt: 5y Epidemiological Study. Int Eye Sci (2015) 15(10):1675-9. doi: $10.3980 /$ j.issn.1672-5123.2015.10.01

33. Schaefer F, Bruttin O, Zografos L, Guex-Crosier Y. Bacterial Keratitis: A Prospective Clinical and Microbiological Study. Br J Ophthalmol (2001) 85 (7):842-7. doi: 10.1136/bjo.85.7.842

34. Stapleton F, Keay LJ, Sanfilippo PG, Katiyar S, Edwards KP, Naduvilath T. Relationship Between Climate, Disease Severity, and Causative Organism for Contact Lens-Associated Microbial Keratitis in Australia. Am J Ophthalmol (2007) 144(5):690-98.e1. doi: 10.1016/j.ajo.2007.06.037

35. Cheng KH, Leung SL, Hoekman HW, Beekhuis WH, Mulder PG, Geerards AJ, et al. Incidence of Contact-Lens-Associated Microbial Keratitis and Its Related Morbidity. Lancet (1999) 354(9174):181-5. doi: 10.1016/S0140-6736 (98)09385-4

36. Lam DS, Houang E, Fan DS, Lyon D, Seal D, Wong E. Incidence and Risk Factors for Microbial Keratitis in Hong Kong: Comparison With Europe and North America. Eye (Lond) (2002) 16(5):608-18. doi: 10.1038/ sj.eye. 6700151

37. Hedayati H, Ghaderpanah M, Rasoulinejad SA, Montazeri M. Clinical Presentation and Antibiotic Susceptibility of Contact Lens Associated Microbial Keratitis. J Pathog (2015) 2015:1-5. doi: 10.1155/2015/152767

38. Mohammadpour M, Mohajernezhadfard Z, Khodabande A, Vahedi P. Antibiotic Susceptibility Patterns of Pseudomonas Corneal Ulcers in Contact Lens Wearers. Middle East Afr J Ophthalmol (2011) 18(3):228-31. doi: 10.4103/0974-9233.84053

39. Rasoulinejad SA, Sadeghi M, Montazeri M, Hedayati Goudarzi H, Montazeri M, Akbarian N. Clinical Presentation and Microbial Analyses of Contact Lens Keratitis; an Epidemiologic Study. Emerg (Tehran) (2014) 2(4):174-7.

40. Singh S, Satani D, Patel A, Vhankade R. Colored Cosmetic Contact Lenses: An Unsafe Trend in the Younger Generation. Cornea (2012) 31(7):777-9. doi: 10.1097/ICO.0b013e31823cbe9c

41. Vardakas KZ, Siempos II, Grammatikos A, Athanassa Z, Korbila IP, Falagas ME. Respiratory Fluoroquinolones for the Treatment of CommunityAcquired Pneumonia: A Meta-Analysis of Randomized Controlled Trials. Cmaj (2008) 179(12):1269-77. doi: 10.1503/cmaj.080358

42. Willcox MD. Management and Treatment of Contact Lens-Related Pseudomonas Keratitis. Clin Ophthalmol (Auckland N Z) (2012) 6:919-24. doi: $10.2147 /$ OPTH.S25168

43. Mattila JS, Holopainen J. Keratitis Associated With Contact Lens Wear. Duodecim (2013) 129(18):1901-7.

44. Eggink CA, Oliveira Dos Santos C, Randag AC, Wijdh RJ. Infectious Keratitis in Contact Lens Wearers. Ned Tijdschr Geneeskd (2019) 163.

45. Zimmerman AB, Nixon AD, Rueff EM. Contact Lens Associated Microbial Keratitis: Practical Considerations for the Optometrist. Clin Optom (2016) 8:1-12. doi: 10.2147/OPTO.S66424

46. Babich T, Naucler P, Valik JK, Giske CG, Benito N, Cardona R, et al. Ceftazidime, Carbapenems, or Piperacillin-Tazobactam as Single Definitive Therapy for Pseudomonas Aeruginosa Bloodstream Infection: A Multisite Retrospective Study. Clin Infect Dis (2020) 70(11):2270-80. doi: 10.1093/cid/ciz668

47. Chew FLM, Soong T, Shin HC, Samsudin A, Visvaraja S. Topical Piperacillin/ Tazobactam for Recalcitrant Pseudomonas Aeruginosa Keratitis. J Ocul Pharmacol Ther (2010) 26: (2):219-22. doi: 10.1089/jop.2009.0077

Conflict of Interest: The authors declare that the research was conducted in the absence of any commercial or financial relationships that could be construed as a potential conflict of interest.

Publisher's Note: All claims expressed in this article are solely those of the authors and do not necessarily represent those of their affiliated organizations, or those of the publisher, the editors and the reviewers. Any product that may be evaluated in this article, or claim that may be made by its manufacturer, is not guaranteed or endorsed by the publisher.

Copyright (c) 2021 Hatami, Ghaffari Jolfayi, Ebrahimi, Golmohammadi, Zangiabadian and Nasiri. This is an open-access article distributed under the terms of the Creative Commons Attribution License (CC BY). The use, distribution or reproduction in other forums is permitted, provided the original author(s) and the copyright owner(s) are credited and that the original publication in this journal is cited, in accordance with accepted academic practice. No use, distribution or reproduction is permitted which does not comply with these terms. 